\title{
Changes in Soil Physical Properties as a Result of Different Land Use Systems with Depth
}

\author{
V.P. Bhavya*, S. Anil Kumar, Ashok Alur, M. Shivanna and K.M. Shivakumar \\ Department of Soil Science and Agricultural Chemistry, College of Horticulture, \\ Bengaluru-560 065, Karnataka, India \\ *Corresponding author
}

\section{A B S T R A C T}

\begin{tabular}{|l|}
\hline K e y w o r d s \\
$\begin{array}{l}\text { Land use systems, } \\
\text { Organic matter } \\
\text { accumulation, Bulk } \\
\text { density, Total } \\
\text { porosity, Maximum } \\
\text { water holding capacity }\end{array}$ \\
\hline Article Info \\
\hline $\begin{array}{l}\text { Accepted: } \\
\text { 04 December } 2017 \\
\text { Available Online: } \\
\text { 10 January } 2018\end{array}$ \\
\hline
\end{tabular}

\section{Keywords}

Land use system density, Total porosity, Maximum water holding capacity

Accepted: 04 December 2017 10 January 2018
The main objective of this study was to assess the physical properties of the soil under different cropping systems within the same locality and interpret the results with reference to organic matter accumulation in soil with twenty year old cultivated crops. The soil samples were collected from different depths at $0-15 \mathrm{~cm}, 15-30 \mathrm{~cm}, 30-50 \mathrm{~cm}$ and $50-$ $100 \mathrm{~cm}$ from a cashew, mango, rose, vegetable and medicinal and aromatic cropping systems and analysed for bulk density, water holding capacity and percentage of pore space. Water holding capacity and percentage of pore space recorded maximum in the surface layer whereas the bulk density recorded maximum in the subsurface layer of the soil. Among different land use systems, vegetable block had higher bulk density values and lowest values was recorded under the mango and cashew orchard whereas, the maximum water holding capacity and percentage of pore space was higher under the perennial crops and lowest values was recorded under the annual crops. It was found that the continuous addition of organic matter under perennial crops helps to increase the physical properties of the soil and maintain the soil health as compared to annual crops.

\section{Introduction}

Soils are composed of solids (minerals and organic matter), and pores which hold air and water. The bulk density of a soil sample of known volume is the mass (or weight) of that sample divided by the bulk volume.

The "ideal" soil would hold sufficient air and water to meet the needs of plants with enough pore space for easy root penetration, while the mineral soil particles would provide physical support and plant essential nutrients. Bulk density is influenced by the amount of soil organic matter (SOM), their texture, constituent minerals and porosity.

The term SOM has been used to encompass all organic materials found in soil (Stevenson, 1994), excluding charcoal (Oades, 1988) and partial decomposed products and non-decayed plant and animal tissues (McCarthy et al., 1990). It ranged from as low as < 0.5 per cent carbon in Aridisols to 33 per cent in Histosols (Sombroek et al., 1993). The organic fraction can exert a profound influence on soil properties and ecosystem functioning (Baldock and Nelson, 2001). 
Soil organic carbon (SOC) has been recognized as the sensitive indicator of sustainability of an ecosystem (Doran, 2002). Long term studies have shown the benefits of manures, adequate fertilization and crop rotation in maintaining agronomic productivity by increasing the $\mathrm{C}$ inputs into soils (Reeves, 1997). The maintenance of adequate levels of SOM through application of crop residues, green manures, FYM and biosolids are important in maintaining the soil fertility and sustainable production.

Soil organic matter is the primary source of, and a temporary sink for, plant nutrients in cultivated soils. Its importance in maintaining soil tilth, aiding the infiltration of air and water, promoting water retention, building soil aggregation, and controlling the fate of applied pesticides is well known (Srinivasan $e t$ al., 2012).

Growing of perennial horticulture crops is one of the strategies to improve soil conditions which would result in enhancing soil attributes and contributing to the good health of the soil. Although the benefits of perennial horticulture crops on soil in improving its physical properties have been well known, information on the changes that would take place on shifting from one farming system to another farming system is lacking.

The present study is a modest attempt to assess the soil physical properties under diverse horticultural cropping systems. This study is not intended to convey, that only perennial horticulture crops is good. However, it is an impartial assessment of the advantages and disadvantages of annual and perennial crops cultivation.

\section{Materials and Methods}

In order to achieve the objective of the experiment, the present investigation was carried out at division of horticulture, UAS Campus, GKVK, Bengaluru, Karnataka during 2015. The soil of the experimental site was sandy loam and classified as fine, mixed isothermic Kandic Paleustalf of Vijayapura soil series. Horticultural crops viz., mango, cashew, rose, vegetable and medicinal and aromatic crops (Sugandhavana) were selected for the experiment within the same locality.

The experimental plots were permanently laid out for specified crops. Soil samples were collected from four different depths i.e., 0-15, $15-30,30-50$, and $50-100 \mathrm{~cm}$. In addition, soil cores were collected using core sampler for the determination of bulk density of the soil.

Soil samples were processed by drying under the shade, powdering with a clean wooden mallet and passing through a $2 \mathrm{~mm}$ sieve. The processed samples were stored in polyethylene bags for analysis in the laboratory. The statistical analysis was done by using Randomized Complete Block Design (RCBD).

\section{Analysis of soil samples for physical properties}

Bulk density of soil sample was determined by using core sampler technique (Black, 1965) recording the fresh weight of the sample in the field and dry weight of the sample in the laboratory. Drying of soil was done in hot air oven to constant weight. Bulk density was calculated as dry weight of soil per unit volume of the core collected by the core sampler in the field.

Keen Raczkowski cups were used for measurement of maximum water holding capacity of soil as outlined by Piper (1966).

The pore space of a soil is that portion of the soil volume occupied by air and water and is calculated by using the below formula. 
$\mathrm{PS}=\mathrm{Vp} / \mathrm{Vt}$ or PS $=[1-(\mathrm{Db} / \mathrm{Dp})]$

Where:

$\mathrm{Vp}=$ Volume of the pores *

$\mathrm{Vt}=$ Total volume of the sample, pore volume + solid volume $\left(\mathrm{cm}^{3}\right)$.

* $\mathrm{Vp}$ is difficult to measure, so it is more common to calculate PS from Bulk density and particle density.

\section{Results and Discussion}

\section{Bulk density under different land use systems}

Bulk density at different depths as influenced by different horticulture crops is presented in Figure 1.

Bulk density of a soil is a dynamic property that varies with the soil structural conditions. In general, it increases with profile depth due to changes in organic matter content, porosity and compaction. Bulk density of the soil changed significantly over years of cultivation of perennial and annual crops. It was found that the higher bulk density values were recorded in the subsurface layers of the soil $(50-100 \mathrm{~cm})$ as compared to surface layers and it was observed that bulk density was increased with increase in soil depth.

Among different cropping systems, the medicinal and aromatic block $\left(1.56 \mathrm{Mg} \mathrm{cm}^{-3}\right)$ had higher bulk density followed by vegetable block $\left(1.55 \mathrm{Mg} \mathrm{cm}^{-3}\right)$ and significantly lowest values were recorded under the mango orchard $\left(1.50 \mathrm{Mg} \mathrm{cm}^{-3}\right)$ at $50-100 \mathrm{~cm}$ soil depth. This is due to the continuous addition of organic matter with minimum tillage treatments under perennial crops reduces the breakdown of soil aggregates which helps to reduce the bulk density. However in case of annual crops due to continuous cultivation, the soil aggregates are broken down into small soil particles, as the size of the soil particles decreases the bulk density increases.

Fig.1 MO- Mango Orchard, VB- Vegetable Block, CO- Cashew Orchard, MAP's- Medicinal and Aromatic Plants, RB- Rose Block

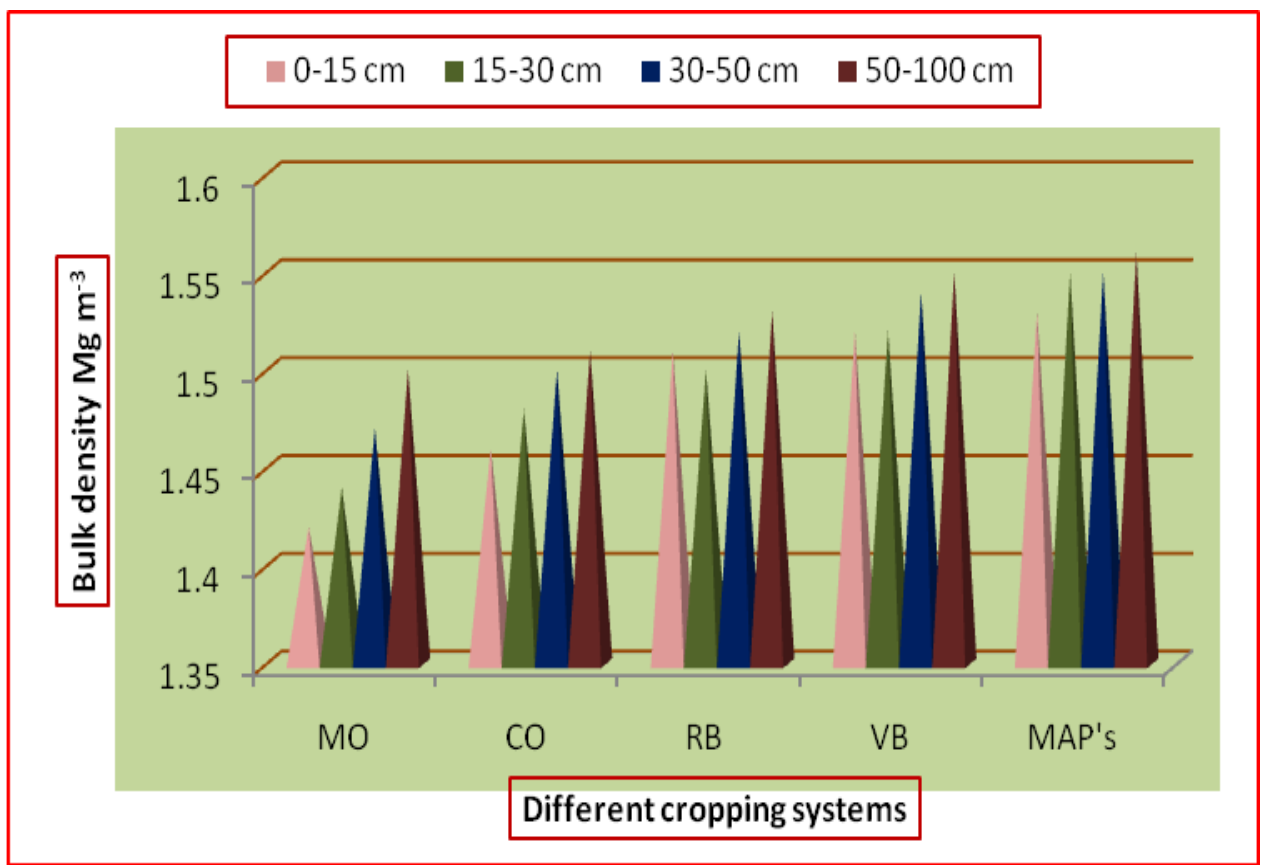


Table.1 Maximum water holding capacity (MWHC) at different depths as influenced by different horticulture crops

\begin{tabular}{|l|c|c|c|c|}
\hline \multicolumn{1}{|c|}{ Horticulture land use system } & \multicolumn{4}{|c|}{ MWHC (\%) } \\
\cline { 2 - 5 } & $0-15 \mathrm{~cm}$ & $15-30 \mathrm{~cm}$ & $30-50 \mathrm{~cm}$ & $50-100 \mathrm{~cm}$ \\
\hline Mango orchard & 43.51 & 42.41 & 41.00 & 40.24 \\
\hline Cashew orchard & 42.88 & 41.25 & 41.00 & 40.11 \\
\hline Rose block & 39.41 & 39.21 & 38.96 & 38.90 \\
\hline Vegetable block & 36.41 & 36.00 & 35.93 & 35.41 \\
\hline Medicinal and aromatic block & 37.19 & 36.28 & 36.00 & 35.26 \\
\hline SEm \pm & 2.01 & 2.11 & 1.68 & 1.51 \\
\hline CD at 5\% & 6.22 & 6.33 & 4.97 & 4.66 \\
\hline
\end{tabular}

Table.2 Pore space percentage at different depths as influenced by different horticulture crops

\begin{tabular}{|l|} 
Horticulture land use system \\
\hline Mango orchard \\
\hline Cashew orchard \\
\hline Rose block \\
\hline Vegetable block SEm \pm \\
\hline Medicinal and aromatic block \\
\hline CD at 5\% \\
\hline
\end{tabular}

Maximum water holding capacity (MWHC) under different land use systems

The maximum water holding capacity (MWHC) of the soil differs at varied depth, the MWHC value of surface soil $(0-15 \mathrm{~cm})$ was slightly higher than subsurface $(30-50 \mathrm{~cm}$ and $50-100$ $\mathrm{cm})$ layer. Among different land use systems, mango orchard had higher water holding capacity $(43.51 \%)$ which is on par with cashew orchard (42.88\%). However, lowest MWHC was observed under vegetable block $(36.41 \%)$.

\section{Pore space percentage under different land use systems}

The pore space percentage is slightly higher in the surface layers i.e., in $0-15 \mathrm{~cm}$ depth than subsurface layer of the soil i.e., $30-50 \mathrm{~cm}$ and $50-100 \mathrm{~cm}$. The percentage of pore space was slightly decreased with increase in depth. Among different cropping systems, the cashew

\section{Pore space $(\%)$}

\begin{tabular}{|c|c|c|c|}
\hline $0-15 \mathrm{~cm}$ & $15-30 \mathrm{~cm}$ & $30-50 \mathrm{~cm}$ & $50-100 \mathrm{~cm}$ \\
\hline 50.62 & 48.44 & 46.71 & 45.71 \\
\hline 52.35 & 49.86 & 48.13 & 46.51 \\
\hline 49.23 & 48.13 & 47.37 & 46.00 \\
\hline 46.75 & 45.31 & 45.00 & 44.34 \\
\hline 48.51 & 47.00 & 46.31 & 45.32 \\
\hline 2.33 & 1.22 & 0.96 & 0.67 \\
\hline 5.89 & 4.22 & 2.86 & 2.00 \\
\hline
\end{tabular}

orchard $(52.35 \%)$ showed significant results which is on par with mango orchard $(50.62 \%)$. The lowest pore space percentage was observed in vegetable block $(46.75 \%)$.

The maximum water holding capacity and pore space percentage was higher in the perennials crops as compared to the annual crops in the 0$15 \mathrm{~cm}$ soil depth (Table 1 and 2). This is due to, it is well known that the moisture retention capacity of the soil is directly related to the total porosity and indirectly related to the bulk density. The continuous addition of organic matter under perennials crops helps in maintaining the soil structure, soil texture (sand, silt and clay) and reduces the soil crust formation thus increases the micro pores and macro pores in soil which helps to increase the moisture retention capacity of the soil in surface layers. As the depth increases, there will be more compaction in the soil as compared to surface layers which decreases the water 
holding capacity. The WHC increases with increasing the level of organic carbon and clay (Ramesh et al., 2008).

Addition of litter biomass might have altered distribution of micro and macro-pores and thus, helped the soil to retain more water (Dagar et $a l$. , 1995). Cultivation practices in agricultural soils and low additions of organic manure might have made the soil more compact and thereby reduced the water holding capacity. Increased bulk densities and reduced water holding capacities in agricultural soils are in concurrence with the above observations. Similar results on higher bulk density in agricultural soils and lower soil moisture constants are reported even in the long-term agricultural experiments under both dry land and irrigated systems (Badanur et al., 1990; Shankar et al., 2003).

From above discussion it was inferred that increase in organic matter content decreases the bulk density of soil. On the other hand increase in organic matter increases the total porosity and water retention capacity of the soil, thus help to maintain the soil texture and structure.

\section{References}

Badanur, V. P., Poleshi, C. M. and Naik, B. K., 1990. Effect of organic matter on crop yield and physical and chemical properties of a Vertisol. J. Indian Soc. Soil Sci., 38: 426-429.

Baldock, J. A. and Nelson, P. N., 2000. Soil Organic Matter. In: Handbook of Soil Science, Sumner, M. E., CRC Press, Boca Raton, FL. pp. B25-B71.

Black, C. A., 1965. Method of soil analysis part II agronomy monograph No, 9, American Society of Agronomy, Madison, Wisconsin, pp.148.
Dagar, J.C., Moniga, A.D. and Singh, N.T., 1995. Degradation of tropical rain forest soils upon replacement with plantations and aerable crops in Andaman and Nicobar Islands in India. Trop. Ecol., 36: 89-101.

Doran, J, W., 2002. Soil health and global sustainability: Translating science into practice. Agri. Ecosys. Environ, 88: 119127.

Oades, J. M., 1988. The retention of organic matter in soils. Biogeochem, 5: 35-70.

Piper, C. S., 1966. Soil and Plant Analysis. Hans Publishers, Bombay.

Ramesh, V., Ballol, S. S., Sharma, K. L., Kausalya, R., Korwar, G. R. and Ramakrishna, Y. S., 2008. Characterization of soil for physical properties under different land uses systems. Indian J. Dry land Agric. Res. Dev. 23(1): 102-109.

Reeves, D. W., 1997. The role of soil organic matter maintaining soil quality in continuous cropping systems. Soil \& Till. Res., 43: 131-167.

Shankar, M.A., Manjunatha, A., Gajanana, G. N., Pandurangaiah, K. Lingappa, B. S., Mariraju, H. and Indrakumar, N., 2003. Three Decades of Dryland Agricultural Research for Alfisols of South Karnataka (1971-2000). AICRP for Dryland Agriculture, UAS, Bangalore.

Sombroek, W.G., Nachtergaele, and Hebel, A., 1993. Amounts, dynamics and sequestering of carbon in tropical and subtropical soils. Ambio, 22: 417-426.

Srinivasan, V., Maheswarappa, H. P. and Lal, R., 2012. Long term effects of topsoil depth and amendments on particulate and non-particulate carbon fractions in a Miamian soil of Central Ohio. Soil Till Res, 121: 10-17.

\section{How to cite this article:}

Bhavya, V.P., S. Anil Kumar, Ashok Alur, M. Shivanna and Shivakumar, K.M. 2018. Changes in Soil Physical Properties as a Result of Different Land Use Systems with Depth. Int.J.Curr.Microbiol.App.Sci. 7(01): 323-327. doi: https://doi.org/10.20546/ijcmas.2018.701.035 